Ambiente \& Água - An Interdisciplinary Journal of Applied Science
ISSN 1980-993X - doi:10.4136/1980-993X
www.ambi-agua.net
E-mail: ambi.agua@gmail.com

\title{
Bioaccumulation of methylmercury in fish tissue from the Roosevelt River, Southwestern Amazon basin
}

\author{
doi:10.4136/ambi-agua.1830
}

Received: 24 Dec. 2015; Accepted: 10 May 2016

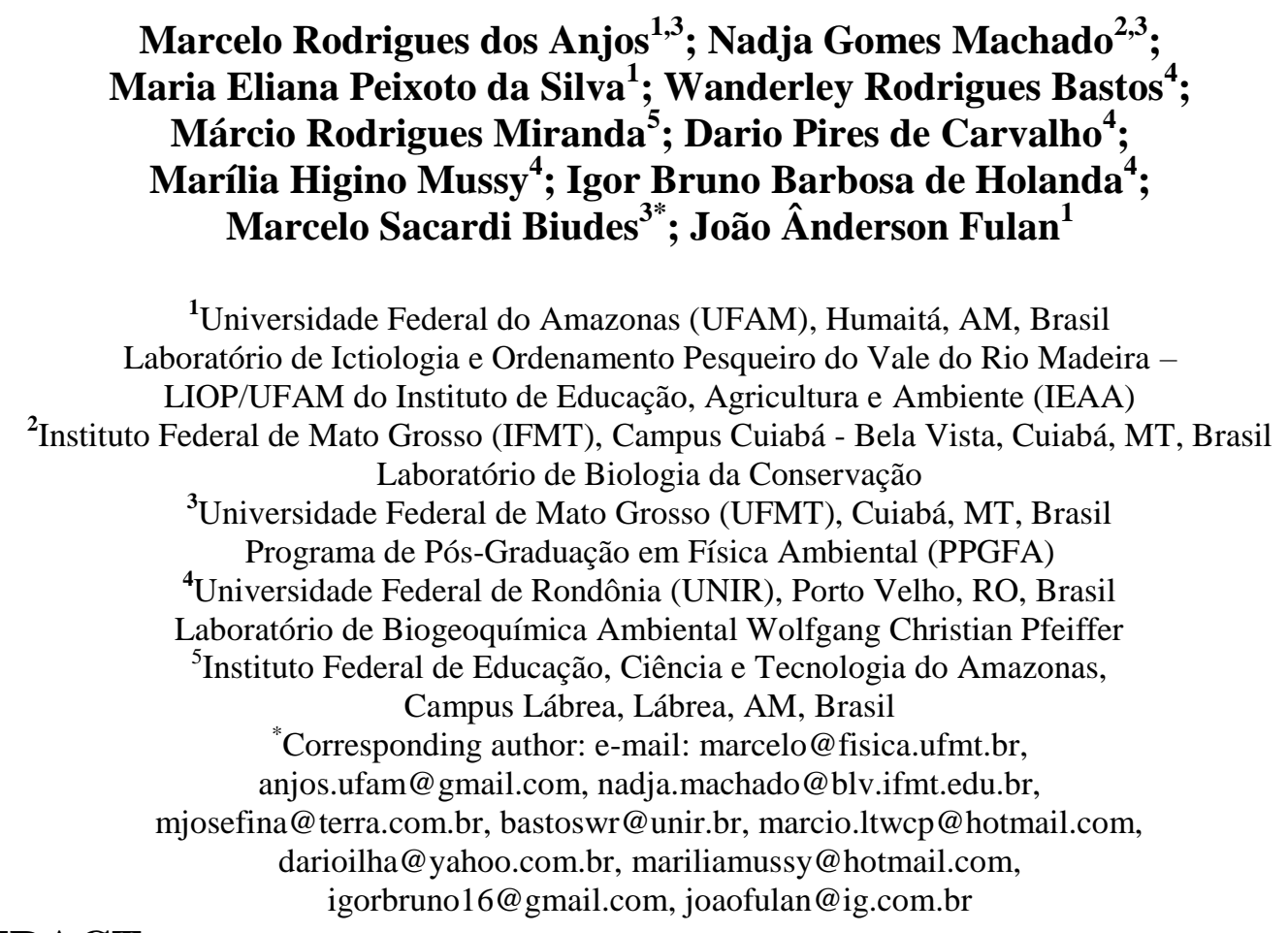

\section{ABSTRACT}

Mercury is a major pollutant in the Amazon River system, and its levels in fish and human hair are usually above the limit recommended by health agencies. The objective of this study was to analyze the methylmercury $(\mathrm{MeHg}$ ) concentration in fish tissue from the Roosevelt River. The river's water velocity, depth, $\mathrm{pH}$, temperature, electrical conductivity, dissolved oxygen and substrate type were measured, and fifty specimens distributed in 14 fish species were collected. A total of $64.3 \%$ of the sampled species were of the order Characiform and $71.4 \%$ of the species were carnivores. Fifty percent of the species had $\mathrm{MeHg}$ concentrations above threshold limit $\left(\mathrm{Hg}-\mathrm{T} 0.5 \mathrm{mg} \mathrm{kg}^{-1}\right)$ established for food by the World Health Organization. Cichla monoculus had the highest value of $\mathrm{MeHg}\left(2.45 \mathrm{mg} \mathrm{kg}^{-1}\right)$. The $\mathrm{MeHg}$ concentration in fish varied according to dietary habits. The study also found bioaccumulation of $\mathrm{MeHg}$ in fish tissue in the following descending order: carnivorous > detritivorous $>$ frugivore. Low significant correlations were found between fish weight or length and $\mathrm{MeHg}$. Further studies on $\mathrm{MeHg}$ contamination are recommended in tissues of fish consumed in human riverine communities in the Roosevelt River Basin.

Keywords: biomagnification, chemical contamination, water pollution. 


\section{Bioacumulação de metilmercúrio em tecidos de peixes no rio Roosevelt, Sudoeste da Bacia Amazônica}

\section{RESUMO}

O mercúrio tem sido um dos principais poluentes no sistema do rio Amazonas, cujos níveis em peixes e cabelo humano são geralmente acima dos limites recomendados pelos órgãos de saúde. O objetivo deste estudo foi analisar a concentração de metilmercúrio ( $\mathrm{MeHg}$ ) em tecidos de peixes do rio Roosevelt. Os atributos medidos do rio foram a velocidade da água, profundidade, $\mathrm{pH}$, temperatura, condutividade elétrica, oxigênio dissolvido, e profundidade. Cinquenta espécimes distribuídas em 14 espécies de peixes foram coletadas. A ordem Characiformes representou 64,3\% das espécies amostradas e os carnívoros representaram $71,4 \%$. Cinquenta por cento das espécies apresentaram concentrações de $\mathrm{MeHg}$ acima do limite (Hg-T 0,5 mg kg${ }^{-1}$ ) estabelecido para os alimentos pela Organização Mundial de Saúde. Cichla monoculus apresentou o maior valor de $\mathrm{MeHg}$ $\left(2,45 \mathrm{mg} \mathrm{kg}^{-1}\right)$. A concentração de $\mathrm{MeHg}$ variou por hábitos alimentares. Este estudo demonstrou bioacumulação de $\mathrm{MeHg}$ em tecidos de peixes, como segue: carnívoros > detritívoros > frugívoros. Baixas correlações entre peso ou cumprimento de peixe e $\mathrm{MeHg}$ foram encontradas. Recomenda-se um estudo mais aprofundado de contaminação do $\mathrm{MeHg}$ em tecidos de peixes consumidos nas comunidades ribeirinhas na bacia do rio Roosevelt.

Palavras-chave: biomagnificação, contaminação química, poluição aquática.

\section{INTRODUCTION}

Mercury $(\mathrm{Hg})$ is one of the most hazardous environmental pollutants, with a large number of physical and chemical forms (Nevado et al., 2010). Although $\mathrm{Hg}$ is a naturally occurring element, anthropogenic activities may also release it into the environment (Cristol et al., 2008), and there has been an increase in the amount currently cycled in the biosphere (Hugget et al., 2001). Complex chemical transformations cause the cycling of $\mathrm{Hg}$ in the environment, although methylmercury $(\mathrm{MeHg})$ formation is the predominant reason for $\mathrm{Hg}$ bioaccumulation in the aquatic food chain (Dorea et al., 2006).

Research has shown that about 60 to $95 \%$ of the total mercury in muscle tissue occurs in the form of $\mathrm{MeHg}$, which is one of the most toxic forms for humans (WHO, 1991). Methylmercury causes brain damage, impaired motor coordination coupled to impaired speech and gait, paresthesia, neurasthenia, tremors, lack of balance, weakness, fatigue, difficulty in concentration, decreased visual field and hearing, and other effects, such as teratogenicity, and can lead to death (Goyer and Clarkson, 2001).

The concentrations of mercury in Amazonian fishes have been a matter of concern for human health and wildlife for over 25 years (Kehrig et al., 2008). Fish constitute an important source of protein for Amazonian riverine population (Dorea et al., 2006) since its excellent, low-fat protein source provides several benefits (Patterson, 2002). High concentrations of mercury found in the Amazonian ecosystem have been usually attributed to gold mining (Nriagu et al., 1992), soils with relatively high concentrations of natural mercury (Lechler et al., 2000), and the atmospheric transport and deposition of mercury from anthropogenic activities (Lacerda, 1995).

While several studies have been conducted in the Amazon involving the contamination of fish by mercury, the Roosevelt River Basin (southwestern Amazon Basin), a potential mercury hotspot, has not yet been investigated for methylmercury. Therefore, the objective of this study was to analyze methylmercury $(\mathrm{MeHg})$ concentration in fish tissue from the Roosevelt River. 


\section{MATERIAL AND METHODS}

\subsection{Study area}

The area under analysis lies on the right bank of the Madeira River, Brazil (Figure 1). The Roosevelt River is a clear water tributary on the right bank of the Aripuanã River, one of the most important tributaries on the east side of the Madeira River Basin. The regional climate according to Köppen classification is Af, which represents a tropical rainforest climate with annual rainfall between 2,300 and 2,750 mm, with January - April as the wettest season (Brasil, 1978). The sampling points are located between parallel $8^{\circ} \mathrm{S}$, and meridians $60^{\circ}$ and $61^{\circ} \mathrm{W}$ (Figure 1; Table 1).

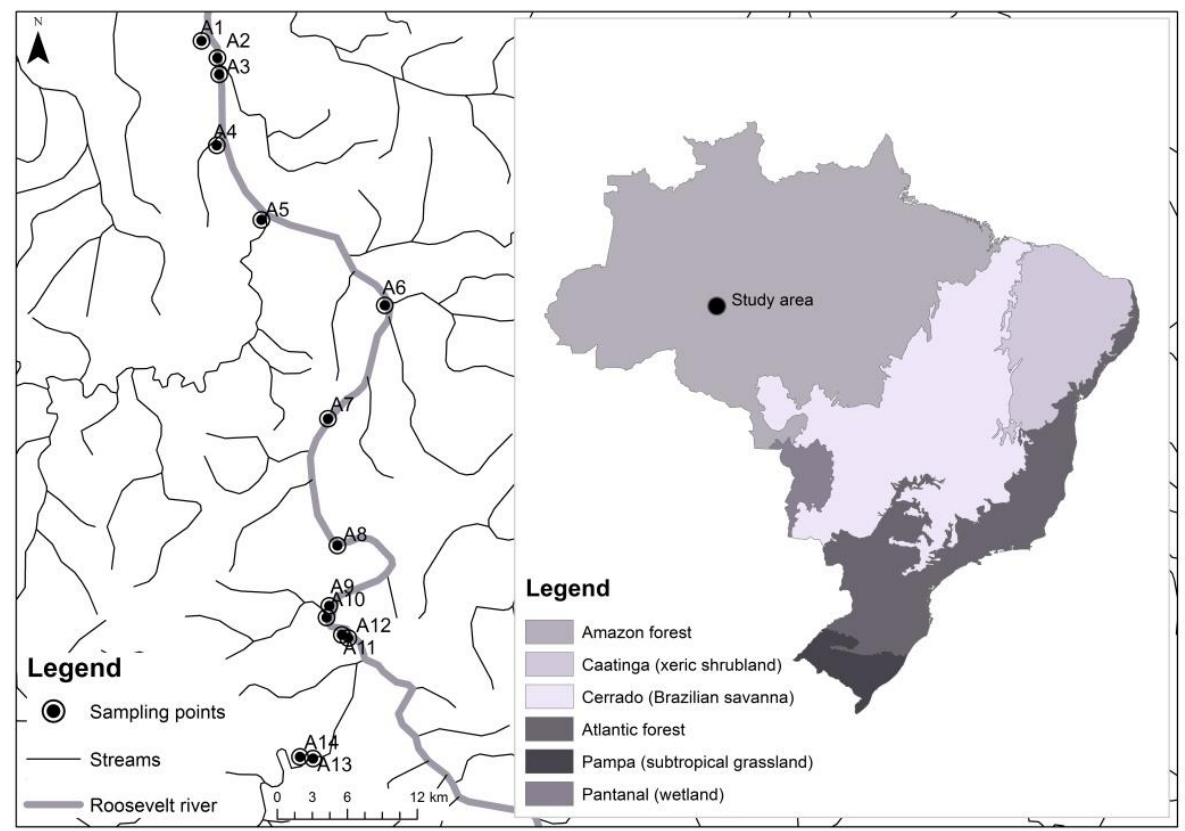

Figure 1. Sampling points at Roosevelt River in the southwestern Amazon Basin, Brazil.

Table 1. Geographical coordinates of sampling points at Roosevelt River in Southwestern Amazon basin, Brazil.

\begin{tabular}{clcc}
\hline Code & \multicolumn{1}{c}{ Site } & Latitude $(\mathrm{S})$ & Longitude $(\mathrm{W})$ \\
\hline A1 & Estação 35 Igarapé da Praia & $8^{\circ} 02^{\prime} 22.1^{\prime \prime}$ & $61^{\circ} 04^{\prime} 36.8^{\prime \prime}$ \\
A2 & Estação 36 Igarapé da Camponesa & $8^{\circ} 03^{\prime} 09.6^{\prime \prime}$ & $61^{\circ} 03^{\prime} 52.8^{\prime \prime}$ \\
A3 & Estação 37 Igarapé do Pavão & $8^{\circ} 03^{\prime} 55.1^{\prime \prime}$ & $61^{\circ} 03^{\prime} 48.0^{\prime \prime}$ \\
A4 & Estação 38 Igarapé da Capela & $8^{\circ} 07^{\prime} 11.4^{\prime \prime}$ & $61^{\circ} 03^{\prime} 54.6^{\prime \prime}$ \\
A5 & Estação 39 Machadinho & $8^{\circ} 10^{\prime} 38.0^{\prime \prime}$ & $61^{\circ} 01^{\prime} 50.9^{\prime \prime}$ \\
A6 & Estação 41 Igarapé do Alfinete & $8^{\circ} 14^{\prime} 35.0^{\prime \prime}$ & $60^{\circ} 56^{\prime} 08^{\prime \prime}$ \\
A7 & Estação 43 Poço da Morcega & $8^{\circ} 19^{\prime} 49.0^{\prime \prime}$ & $60^{\circ} 58^{\prime} 46.5^{\prime \prime}$ \\
A8 & Estação 47 Poço do Diogo & $8^{\circ} 25^{\prime} 40.2^{\prime \prime}$ & $60^{\circ} 58^{\prime} 20.4^{\prime \prime}$ \\
A9 & Estação 51 Cachoeira da Glória & $8^{\circ} 28^{\prime} 27.5^{\prime \prime}$ & $60^{\circ} 58^{\prime} 42.9^{\prime \prime}$ \\
A10 & Estação 52 Poço do Esperança & $8^{\circ} 28^{\prime} 59.7^{\prime \prime}$ & $60^{\circ} 58^{\prime} 50.4^{\prime \prime}$ \\
A11 & Estação 53 Poço da Pirapitinga & $8^{\circ} 29^{\prime} 47.7^{\prime \prime}$ & $60^{\circ} 58^{\prime} 07.9^{\prime \prime}$ \\
A12 & Estação 54 Poço do Santa Rita & $8^{\circ} 29^{\prime} 56.6^{\prime \prime}$ & $60^{\circ} 57^{\prime} 50.3^{\prime \prime}$ \\
A13 & Estação 55 Poço da Pirarara & $8^{\circ} 35^{\prime} 30.4^{\prime \prime}$ & $60^{\circ} 59^{\prime} 27.7^{\prime \prime}$ \\
A14 & Estação 56 Lago do Tucunaré & $8^{\circ} 35^{\prime} 25.8^{\prime \prime}$ & $61^{\circ} 00^{\prime} 04.1^{\prime \prime}$ \\
\hline
\end{tabular}




\subsection{Data collection}

The analyzed attributes of sampling areas were water velocity $\left(\mathrm{m} \mathrm{s}^{-1}\right)$, depth $(\mathrm{m}), \mathrm{pH}$, temperature $\left({ }^{\circ} \mathrm{C}\right)$, electric conductivity $\left(\mu \mathrm{S} \mathrm{cm}^{-1}\right)$, dissolved oxygen $\left(\mathrm{mg} \mathrm{L}^{-1}\right)$ and substrate type ( $>75 \%$ of a substrate type on the channel by visual observation). The fish capture effort was standardized in $500 \mathrm{~m}^{2}$ for 24 hours at each sample point with fish harvested every six hours, using 14 gillnets (10x1.5 m or 10x1.5 m with mesh sizes between adjacent knots: 20, $30,40,50,60,70,80,90,100,120,140,160,180$ and $200 \mathrm{~mm})$. Longlines were also set and exposed at strategic locations near the mouth of each tributary during the collections. Collected fish were fixed in 10\% formaldehyde and conserved in $70 \%$ alcohol, except those used in the $\mathrm{MeHg}$ analysis. Standard length $(\mathrm{cm})$ and total body weight $(\mathrm{g})$ were recorded in the laboratory. Voucher specimens were deposited at the Laboratório de Ictiologia e Ordenamento Pesqueiro do Vale do Rio Madeira - LIOP/UFAM.

\subsection{MeHg analysis}

After collection, fish were properly identified, measured and weighed. After these procedures, approximately $20 \mathrm{~g}$ (wet weight) of muscle samples were immediately cut, frozen and transported to the biogeochemistry laboratory at the Federal University of Rondônia for analysis.

The method described by EPA-Method 1630 (USEPA, 2001) and Liang et al. (1994) was used for the $\mathrm{MeHg}$ determination in the fish muscle. A known amount $(200 \mathrm{mg}$ ) of muscle tissue (wet weight) was weighed in a PTFE tube and $5.0 \mathrm{~mL}$ of $25 \%(\mathrm{w} / \mathrm{v}) \mathrm{KOH}$ methanolic solution was used to extract the $\mathrm{MeHg}$ in an oven with the temperature controlled at $70{ }^{\circ} \mathrm{C}$ (Nova Instruments, Model NI 1512, São Paulo, Brazil) for $6 \mathrm{~h}$ with gentle stirring every hour. The samples were then kept in the dark to avoid possible degradation of the $\mathrm{MeHg}$. Subsequently, the ethylation process was done with $300 \mu \mathrm{L}$ of $272 \mathrm{~g} \mathrm{~L}^{-1}$ sodium acetate buffer (pH 4.5), followed by the addition of $30 \mu \mathrm{L}$ of sample and $50 \mu \mathrm{L}$ of tetra ethyl sodium borate solution (1\% w/v) according to Taylor et al. (2011). The final volume was brought to $40.0 \mathrm{~mL}$ with ultra-pure water (milli-Q, Millipore, Cambridge, MA, USA) and analyzed on a MERXTM automated MeHg system from Brooks Rand Labs (Seattle, USA) equipped with an auto-sampler, a purge and trap unit, a packed column GC/pyrolysis unit, and a Model III atomic fluorescence spectrophotometer.

Method accuracy of $\mathrm{MeHg}$ determinations were ensured by the use of certified material (Dogfish Muscle, DORM-2, National Research Council of Canada, Ottawa) which was run with each batch of samples with a mean recovery of $108 \% \mathrm{MeHg}$.

\subsection{Statistical analysis}

We assumed the WHO threshold limit of $0.50 \mathrm{mg} \mathrm{kg}^{-1}$ for $\mathrm{Hg}$ (WHO, 1991) as the threshold limit for $\mathrm{MeHg}$. Estimates of $\mathrm{MeHg}$ averages ( $\pm 95 \%$ confidence interval) were calculated for species and trophic composition measurements by bootstrapping the resampled time series over 1,000 interactions (Efron and Tibshirani, 1993). The confidence interval is a range of values calculated by statistical methods which includes the desired true parameter, the mean in this case. Confidence interval is an alternative to null hypothesis significance testing because it provides information about the probability of the sign of an effect (Natrella, 1960; Berry, 1986; Gardner \& Altman, 1986; Brandstätter \& Linz, 1999). The confidence intervals were calculated by the 'boot' package in R program (R Core Team, 2015).

\section{RESULTS AND DISCUSSION}

Mean water velocity was $7.0 \mathrm{~m} \mathrm{~s}^{-1}$, electric conductivity was $6.8 \mu \mathrm{S} \mathrm{cm} \mathrm{cm}^{-1}$, mean depth was $4.3 \mathrm{~m}, \mathrm{pH}$ ranged from 5.6 to 8.0 , mean temperature was $29.3^{\circ} \mathrm{C}$, and mean dissolved 
oxygen was $9.4 \mathrm{mg} \mathrm{L}^{-1}$ (Table 2). The substrate type of the river channel was mainly composed of coarse litter and bedrock.

Table 2. Environmental attributes of sampling points at Roosevelt River in the southwestern Amazon Basin, Brazil. DO = dissolved oxygen.

\begin{tabular}{cccccccc}
\hline Code & $\begin{array}{c}\text { Water velocity } \\
\left(\mathrm{m} . \mathrm{s}^{-1}\right)\end{array}$ & $\begin{array}{c}\text { Depth } \\
(\mathrm{m})\end{array}$ & $\begin{array}{c}\text { Conductivity } \\
\left(\mu \mathrm{S} . \mathrm{cm}^{-1}\right)\end{array}$ & $\mathrm{pH}$ & $\begin{array}{c}\text { Temperature } \\
\left({ }^{\circ} \mathrm{C}\right)\end{array}$ & $\begin{array}{c}\text { DO } \\
\left(\mathrm{mg} . \mathrm{L}^{-1}\right)\end{array}$ & $\begin{array}{c}\text { Substrate } \\
\text { type }(75 \%)\end{array}$ \\
\hline A1 & 5.80 & 4.30 & 7.25 & 6.7 & 29.7 & 7.7 & Sand \\
A2 & 5.30 & 2.80 & 7.75 & 6.6 & 28.5 & 7.3 & Coarse litter \\
A3 & 7.30 & 2.77 & 6.50 & 5.6 & 27.4 & 10.0 & Coarse litter \\
A4 & 5.20 & 3.40 & 6.00 & 6.8 & 29.0 & 8.9 & Coarse litter \\
A5 & 10.70 & 2.21 & 6.75 & 5.9 & 29.1 & - & Sand \\
A6 & 3.55 & 3.20 & 5.00 & 6.7 & 31.0 & - & Bedrock \\
A7 & 7.20 & 3.70 & 7.75 & 6.7 & 30.2 & 12.8 & Bedrock \\
A8 & 7.30 & 5.00 & 5.75 & 6.6 & 29.2 & 8.3 & Bedrock \\
A9 & 7.30 & 9.00 & 7.75 & 6.6 & 28.9 & 11.1 & Bedrock \\
A10 & 6.00 & 7.50 & 6.75 & 6.7 & 29.6 & 10.0 & Sand \\
A11 & 15.00 & 3.90 & 6.50 & 6.7 & 29.0 & 10.1 & Bedrock \\
A12 & 5.60 & 2.25 & 8.00 & 6.6 & 29.1 & 11.0 & Bedrock \\
A13 & 6.90 & 4.30 & 6.00 & 6.7 & 30.0 & 8.9 & Bedrock \\
A14 & 4.82 & 5.45 & 8.00 & 6.2 & 30.1 & 7.0 & Coarse litter \\
\hline Mean & $\mathbf{7 , 0}$ & $\mathbf{4 , 3}$ & $\mathbf{6 , 8}$ & $\mathbf{6 , 5}$ & $\mathbf{2 9 , 3}$ & $\mathbf{9 , 4}$ & \\
\hline & & & & & & & \\
\hline
\end{tabular}

A total of 50 individuals from 14 fish species were collected and analyzed in the Madeira River Basin (Table 3). A total of $64.3 \%$ of the sampled species were of the order Characiform, followed by the Perciform (21.4\%) and Siluriform (14.3\%) orders. Fish were grouped according to preferential feeding habits. Carnivores represented $71.4 \%$ of the sampled species, while frugivores represented $14.3 \%$ and detritivores and omnivores were $7.1 \%$. The standard length of the fish ranged between 31 and $77.7 \mathrm{~cm}$ and body weight varied from 577.3 to $9,267.3 \mathrm{~g}$. The most abundant species were Prochilodus nigricans, Hydrolycus scomberoides and Boulengerella cuvieri, in that order.

Seven species exceeded the WHO threshold limit, such as Cichla monoculus, Phractocephalus hemioliopterus and Hydrolycus scomberoides (Figure 2). On the other hand, Hydrolycus tatauaia was at the WHO threshold limit and six species showed concentrations below the threshold limit. Carnivorous fish presented a mean total $\mathrm{MeHg}$ value above the WHO threshold limit (Figure 3), showing the importance of the $\mathrm{MeHg}$ bio magnification. No detritivore, omnivore and frugivore fish (4 spp.) showed concentrations above the threshold limit.

The low positive correlation was significant ( $\mathrm{p}$-value $>0.05)$ between length (0.39) or weight (0.49) and $\mathrm{MeHg}$ for fish in the study area. The strong positive correlation was significant between weight and length (0.86). 
Table 3. Fish species, number of individuals $(\mathrm{N})$, trophic level, standard length $(\mathrm{cm})$, total body weight (g) in Roosevelt River in the southwestern Amazon basin, Brazil. Values in parentheses mean confidence interval.

\begin{tabular}{lcccr}
\hline \multicolumn{1}{c}{ Species } & $\mathrm{N}$ & Trophic level & Length $(\mathrm{cm})$ & Weight $(\mathrm{g})$ \\
\hline Boulengerella cuvieri & 6 & Carnivore & $55.7(5.7)$ & $1791.6(558.3)$ \\
Cichla monoculus & 1 & Carnivore & $38.0(0.0)$ & $1500.0(0.0)$ \\
Cichla orinocensis & 1 & Carnivore & $44.0(0.0)$ & $1380.0(0.0)$ \\
Hydrolycus scomberoides & 7 & Carnivore & $52.5(13.2)$ & $2932.0(1950.0)$ \\
Hydrolycus tatauaia & 4 & Carnivore & $37.8(2.9)$ & $577.3(150.0)$ \\
Leiarius marmoratus & 1 & Carnivore & $70.0(0.0)$ & $8600.0(0.0)$ \\
Leporinus friderici & 1 & Omnivore & $32.0(0.0)$ & $840.0(0.0)$ \\
Myleus pacu & 3 & Frugivore & $35.3(4.5)$ & $1271.3(225.0)$ \\
Myleus torquatus & 3 & Frugivore & $33.3(2.0)$ & $1263.4(225.0)$ \\
Phractocephalus hemioliopterus & 2 & Carnivore & $77.7(10.0)$ & $9267.3(4350.0)$ \\
Plagioscion squamosissimus & 2 & Carnivore & $48.5(1.5)$ & $2322.1(325.0)$ \\
Prochilodus nigricans & 11 & Detritivore & $37.9(3.7)$ & $1148.9(308.7)$ \\
Serrasalmus rhombeus & 4 & Carnivore & $31.0(4.0)$ & $761.8(560.0)$ \\
Serrasalmus spilopleura & 4 & Carnivore & $35.8(4.2)$ & $1311.7(528.7)$ \\
\hline & & & &
\end{tabular}

Only carnivores exhibited methylmercury (MeHg) concentrations above the WHO threshold limit in food for human consumption. The results highlight carnivorous fish as good indicators of contamination by $\mathrm{MeHg}$ and indicate the occurrence of $\mathrm{MeHg}$ bio magnification in food webs for fish in the southwestern Amazon Basin. Several studies indicated Madeira River and its tributaries, such as the Roosevelt River, as the principal route in $\mathrm{Hg}$ exportation to their associated aquatic systems due to soil erosion caused by forest burning, extensive cattle ranching, soybean plantations and cassiterite mining (Lechler et al., 2000).

As expected for neotropical rivers, fish of the Characiform order were the most abundant sampled species in the Roosevelt River (Lowe-McConnel, 1999). In fact, they include the most important commercial and subsistence fish of South American inland waters (Ardura et al., 2010). Some carnivore fish species consumed by the population have considerable potential for bioaccumulation due to their position at the top of the aquatic food chain (Dorea et al., 2006). These include Cichla monoculus (tucunaré-amarelo) and Phractocephalus hemioliopterus (pirarara), which are inappropriate for human consumption (Bastos et al., 2008). In the case of Cichla, its feeding habits evolve from planktivore in the early to piscivorous in the mature stage (Kehrig et al., 2008). On the other hand, herbivorous fish species consumed by the population, such as Myleus torquatus (pacú-branco) were not inappropriate for human consumption, even though the herbivore pacú-branco may have higher $\mathrm{Hg}$ concentrations during the rainy season (Dorea et al., 2006). 


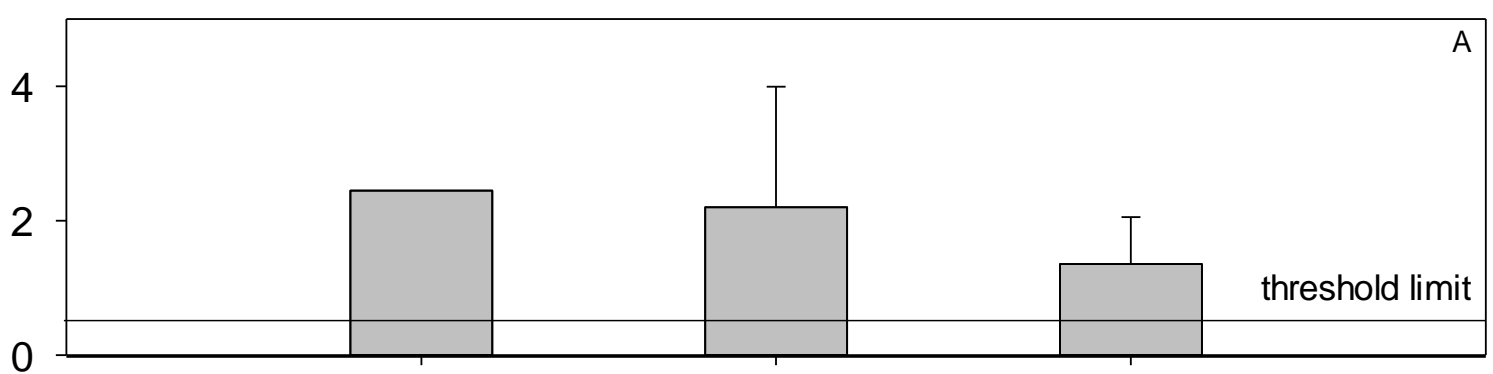

C. monoculus P. hemioliopterus H.scomberoides
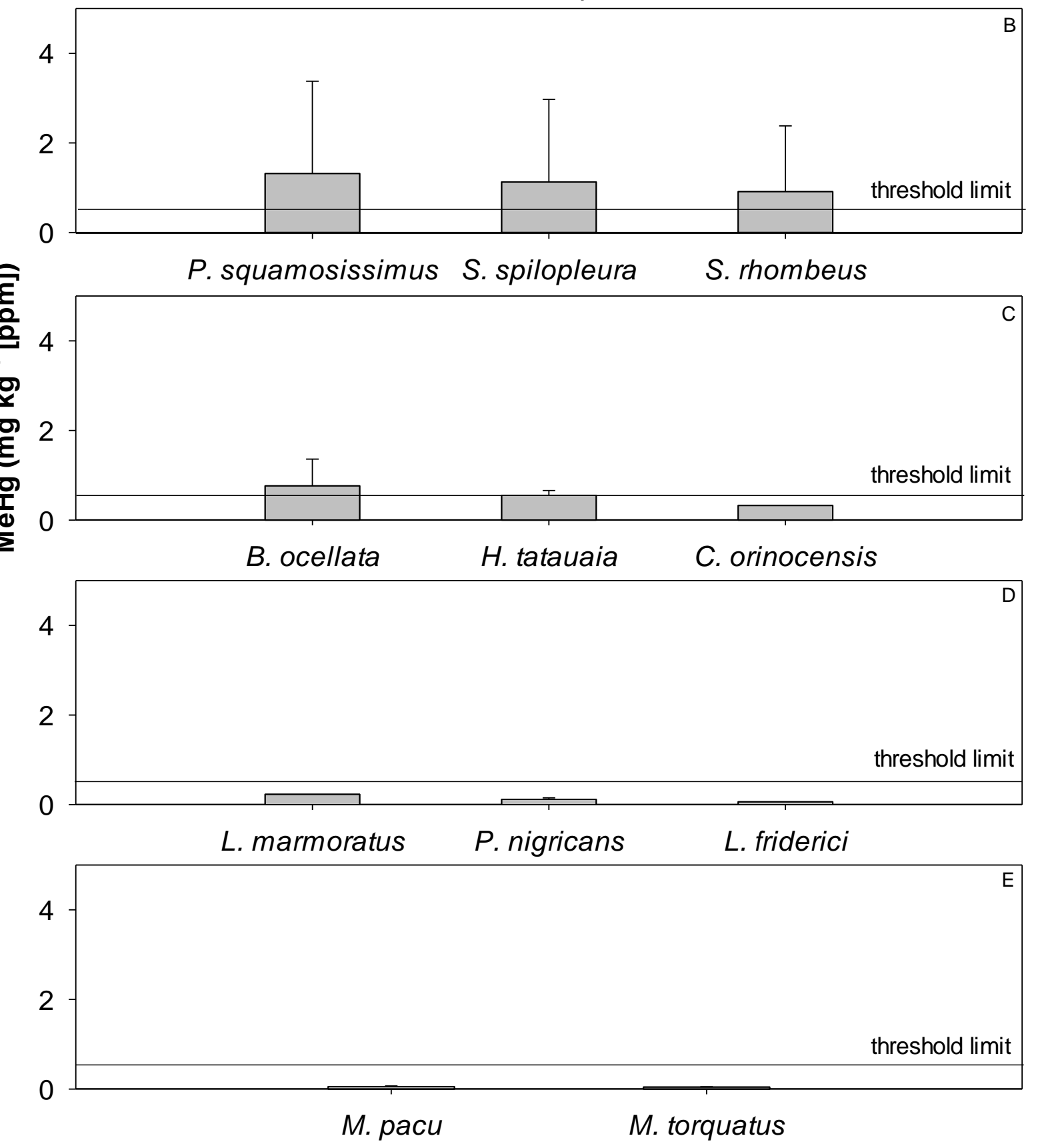

Figure 2. Concentration of MeHg in fish tissue of sampled species at Roosevelt River in the southwestern Amazon Basin, Brazil. Bars represent $\pm 95 \%$ confidence interval. 


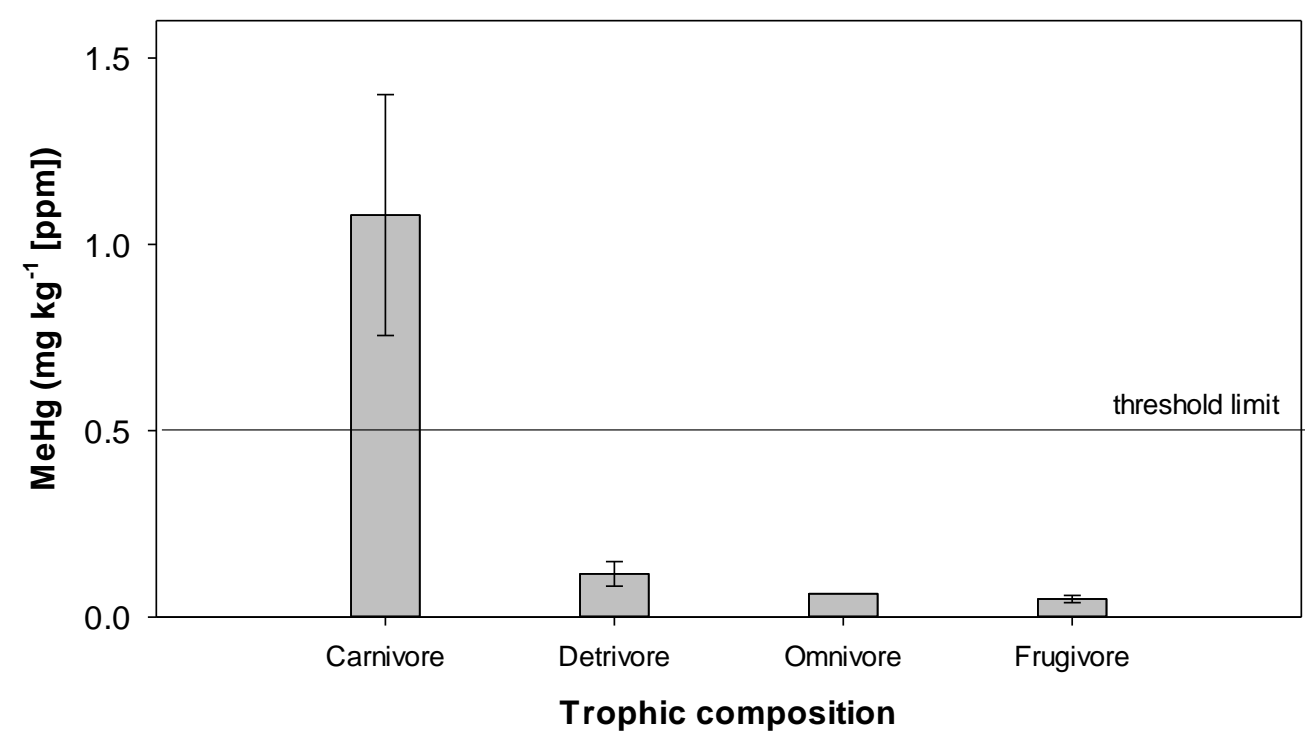

Figure 3. Concentrations of $\mathrm{MeHg}$ in fish tissues by fish trophic composition at Roosevelt River in the southwestern Amazon Basin, Brazil. Bars represent $\pm 95 \%$ confidence interval.

Amaro et al. (2014) recorded a seasonal variation in $\mathrm{Hg}$ level with higher rates at the end of the dry season, in contrast to results by Coelho et al. (2007) in which rainfall has a strong influence in $\mathrm{Hg}$ levels in aquatic environments. This is due to leaching, which increases the availability of organic matter and enhances the bio-magnification process in the river sediment. Some water bodies have favorable characteristics for the mobilization of mercury and organification, such as subanoxia, anoxia, low $\mathrm{pH}$, and high dissolved organic matter (Lacerda and Malm, 2008).

Regular annual flooding alters the aquatic environment and affects fish feeding strategies (Dorea et al., 2006). They reported fish, debris and insects as the most important food resources throughout the year, while the percentages of fruit, invertebrates and fish were reduced during the low-water period. Regardless of hydrological period effects, ranges of total $\mathrm{Hg}$ concentrations studied by Dorea et al. (2006) were higher for carnivores than for omnivore, detritivore and herbivore species.

In the case of human populations, one possible exposure route is through the ingestion of contaminated food. This is highly important for riverine communities, especially for indigenous peoples for whom fish constitutes their daily protein diet (Boischio and Cernichiari, 1998). Malm et al. (1997) showed some areas with both high Hg levels in fish and in samples of human hair in the Madeira and Tapajós Basins in Brazil. In fact, concentrations were high enough to cause negative health effects.

The frequency of consumption and daily intake are essential components in the evaluation of health risks even if the fish consumed contains concentrations of mercury below rates established by sanitary legislation (Brabo et al., 1999). The frequency of consumption constitutes a most important factor in assessing the risk of mercury contamination in communities that do not have alternative food sources (Brabo et al., 1999). Indications of neurotoxic effects related to $\mathrm{MeHg}$ exposure due to fish consumption have been reported in at least one riverine community of the Tapajos River Basin (Grandjean et al., 1999).

Although in current analysis there was a low significant correlation between fish length or weight and $\mathrm{MeHg}$ level in the sampled fish tissue, information on the species weight, size and feeding habits is important in evaluating MeHg bioaccumulation processes (Brabo et al. 1999). According to Roulet and Maury-Brachet (2001), it is rare to observe significant correlations in Amazonian fish. Other authors did not find significant correlation between fish 
length or weight and MeHg level (Brabo et al., 1999; Amaro et al., 2014; Bastos et al., 2008). The current authors underscore that $\mathrm{MeHg}$ contamination may be associated not only to the variability in the diet of each fish species and migration capacity, but also to other variables of aquatic environment, such as flow dynamics, water depth, levels of mercury on the bottom and suspended sediments, and in planktonic and benthic communities (Reuther, 1994).

\section{CONCLUSIONS}

Fifty specimens from 14 fish species were collected and analyzed for contamination by methylmercury $(\mathrm{MeHg})$ in the Madeira River Basin. More than $60 \%$ of the sampled species were of the Characiform order and over $70 \%$ were carnivores. They include the most important commercial and subsistence fish of South American inland waters whose contamination poses a risk to human consumption. Seven species exceeded the WHO threshold limit, such as Phractocephalus hemioliopterus and Hydrolycus scomberoides. Only carnivores exhibited $\mathrm{MeHg}$ concentrations above the WHO threshold limit in food for human consumption which means that they are good indicators of contamination by $\mathrm{MeHg}$. Therefore, $\mathrm{MeHg}$ concentrations in fish varied due to dietary habits. The study also demonstrated that $\mathrm{MeHg}$ bioaccumulation in fish tissue occurs in the following descending order: carnivore $>$ detritivore $>$ frugivore.

\section{REFERENCES}

AMARO, C. S. O.; RODRIGUES JÚNIOR, D.; SILVA, M. C. F.; LIMA, A. A. S.; SANTOS, G. F. S.; PINHEIRO, M. C. N. Concentração de mercúrio total (Hg-T) em peixes comercializados em diferentes períodos sazonais no Mercado do Ver-o-Peso, Belém, Estado do Pará, Brasil. Revista Pan-Amazônica de Saúde, v. 1, p. 53-60, 2014. http://dx.doi.org/10.5123/S2176-62232014000100006

ARDURA, A.; LINDE, A. R.; MOREIRA, J. C.; GARCIA-VAZQUEZ, E. DNA barcoding for conservation and management of Amazonian commercial fish. Biological Conservation, v. 143, p 1438-1443, 2010.

http://dx.doi.org/10.1016/j.biocon.2010.03.019

BASTOS, W. R.; REBELO, M. F.; FONSECA, M. F.; ALMEIDA, R.; MALM, O. A description of mercury in fishes from the Madeira River Basin, Amazon, Brazil. Acta Amazonica, v. 38, n. 3, p. 431-438, 2008. http://dx.doi.org/10.1590/S004459672008000300006

BERRY, G. Statistical significance and confidence intervals. The Medical Journal of Australia, v. 144, p. 618-619, 1986.

BOISCHIO, A. A. P.; CERNICHIARI, E. Longitudinal hair mercury concentration in riverside mothers along the upper Madeira river (Brazil). Environmental Research, v. 77, p. 79-83, 1998. http://dx.doi.org/10.1006/enrs.1998.3831

BRABO, E. S.; SANTOS, E. O.; JESUS, I. M.; MASCARENHAS, A. F.; FAIAL, K. F. Níveis de mercúrio em peixes consumidos pela comunidade indígena de Sai Cinza na Reserva Munduruku, Município de Jacareacanga, Estado do Pará, Brasil. Cadernos de Saúde Pública, v. 15, n. 2, p. 325-331, 1999. http://dx.doi.org/10.1590/S0102311X1999000200017 
BRANDSTÄTTER, E.; LINZ, J. K. U. Confidence intervals as an alternative to significance testing. Methods of Psychological Research Online, v. 4, n. 2, p. 33-46, 1999.

BRASIL. Departamento Nacional de Produção Mineral - DNPM. Levantamento de recursos naturais, Radambrasil, Vol. 17. Folha SB.20 - Purus. Rio de Janeiro, 1978.

COELHO A. S.; MIRANDA, M. R.; GUIMARÃES, R. D. A. Importância das macrófitas aquáticas no ciclo do mercúrio na bacia do rio Tapajós (PA). Oecologia Brasiliensis, v. 11, n. 2, p. 252-63, 2007.

CRISTOL, D. A.; BRASSO, R. L.; CONDON, A. M.; FOVARGUE, R. E.; FRIEDMAN, S. L.; HALLINGER, K. K. et al. The movement of aquatic mercury through terrestrial food webs. Science, v. 320, p. 335, 2008. http://dx.doi.org/10.1126/science.1154082

DOREA, J. G.; BARBOSA, A. C.; SILVA, G. S. Fish mercury bioaccumulation as a function of feeding behavior and hydrological cycles of the Rio Negro, Amazon. Comparative Biochemistry and Physiology. Part C, v. 142, p. 275-283, 2006. http://dx.doi.org/10.1016/j.cbpc.2005.10.014

EFRON, B.; TIBSHIRANI, R. J. An introduction to the bootstrap. New York: Chapman \& Hall, 1993. 443 p.

GARDNER, M. J.; ALTMAN, D. G. Confidence intervals rather than P values: estimation rather than hypothesis testing. British Medical Journal, v. 292, p. 746-750, 1986. http://dx.doi.org/10.1136/bmj.292.6522.746

GOYER, R. A.; CLARKSON, T. W. Toxic effects of metals. In: KLAASSEN, C. D. (Ed.). Casarett and Doull's toxicology: the basic science of poisons. 6. ed. New York: McGraw-Hill, 2001. p. 834-837.

GRANDJEAN, P.; WHITE, R. F.; NIELSEN, A.; CLEARY, D.; SANTOS, E. C. O. Methylmercury neurotoxicity in Amazonian children downstream from gold mining. Environmental Health Perspectives, v. 107, n. 7, p. 587-591, 1999. http://dx.doi.org/10.2307/3434402

HugGeT, D. B.; STEEVEnS, J. A.; AllgoOd, J. C.; LUTKEN, C. B.; GRACE, C. A.; BENSON, W. H. Mercury in sediment and fish from north Mississippi lakes. Chemosphere, v. 42, p. 923-929, 2001. http://dx.doi.org/10.1016/S00456535(00)00175-2

KEHRIG, H. A.; HOWARD, B. M.; MALM, O. Methylmercury in a predatory fish (Cichla spp.) inhabiting the Brazilian Amazon. Environmental Pollution, v. 154, p. 68-76, 2008. http://dx.doi.org/10.1016/j.envpol.2007.12.038

LACERDA, L. D. Amazon mercury emissions. Nature, v. 374, p. 20-21, 1995. http://dx.doi.org/10.1038/374020a0

LACERDA, L. D.; MALM, O. Mercury contamination in aquatic ecosystems: an analysis of the critical areas. Estudos Avançados, v. 22, n. 63, p. 173-190, 2008. http://dx.doi.org/10.1590/S0103-40142008000200011 
LECHLER, P. J.; MILLER, J. R.; LACERDA, L. D.; VINSON, D.; BONZONGO, J. C.; LYONS, W. B.; WARWICK, J. J. Elevated mercury concentrations in soils, sediments, water, and fish of the Madeira River basin, Brazilian Amazon: a function of natural enrichments? The Science of the Total Environment, v. 260, p. 87-96, 2000. http://dx.doi.org/10.1016/S0048-9697(00)00543-X

LIANG, L.; BLOOM, N. S.; HORVAT, M. Simultaneous determination of mercury speciation in biological materials by GC/CVAFS After Ethylation and RoomTemperature Precollection. Clinical Chemistry, v. 40, n.4, p. 602-607, 1994.

LOWE-MCCONNEL, R. H. Estudos ecológicos de comunidades de peixes tropicais. São Paulo: EDUSP, 1999. 536p.

MALM, O.; GUIMARÃES, J. R. D.; CASTRO, M. B.; BASTO, W. R.; VIANA, J. P.; BRANCHES, F. J. P. et al. Follow-up of mercury levels in fish, human hair and urine in the Madeira and Tapajo's Basins, Amazon, Brazil. Water, Air and Soil Pollution, v. 97, p. 45-51, 1997. http://dx.doi.org/10.1007/BF02409643

NATRELLA, M. G. The Relation between confidence intervals and tests of significance-a teaching aid. The American Statistician, v. 14, n. 1, p. 20-22+38, 1960. http://dx.doi.org/10.1080/00031305.1960.10482623

NEVADO, J. J. B.; MARTÍN-DOIMEADIOS, R. C. R.; BERNARDO, F. J. G.; MORENO, M. JIMÉNEZ; HERCULANO, A. M. et al. Mercury in the Tapajós River basin, Brazilian Amazon: A review. Environment International, v. 36, p. 593-608, 2010.

NRIAGU, J. O.; PFEIFFER, W. C.; MALM, O.; SOUZA, C. M. M.; MIERLE, G. Mercury pollution in Brazil. Nature, v. 356, p. 389, 1992.

PATTERSON, J. Introduction-comparative dietary risk: balance the risks and benefits of fish consumption. Comments on Toxicology, v. 8, p. 337-344, 2002. http://dx.doi.org/10.1080/08865140215062

R CORE TEAM. R: A language and environment for statistical computing. Vienna: $R$ Foundation for Statistical Computing, 2015.

REUTHER, R. Mercury accumulation in sediments and fish from rivers affected by alluvial gold mining in the Madeira river basin, Brazil. Ambio, v. 19, p. 11-15, 1994. http://dx.doi.org/10.1007/BF00546279

ROULET, M.; MAURY-BRACHET, R. Le mercure dans les organismes aquatiques amazoniennes. In: CARMOUSE, J. P.; LUCOTTE, M.; BOUDOU, A. (Eds). Le mercure en Amazonie. Paris: Rôle de L'homme et de L'environment, risques sanitaries, 2001. 494p.

TAYLOR, V. F.; CARTER, A.; DAVIES, C.; JACKSON, B. P. Trace-level automated mercury speciation analysis. Analytical Methods, v. 3, n. 5, p. 1143-1148, 2011.

UNITED STATES. Environmental Protection Agency - USEPA. Method 1630: Methyl Mercury in Water by Distillation, Aqueous Ethylation, Purge and Trap, and CVAFS. Washington DC, 2001.

WORLD HEALTH ORGANIZATION - WHO. Environmental health criteria for Inorganic Mercury. Geneva, 1991. 